632

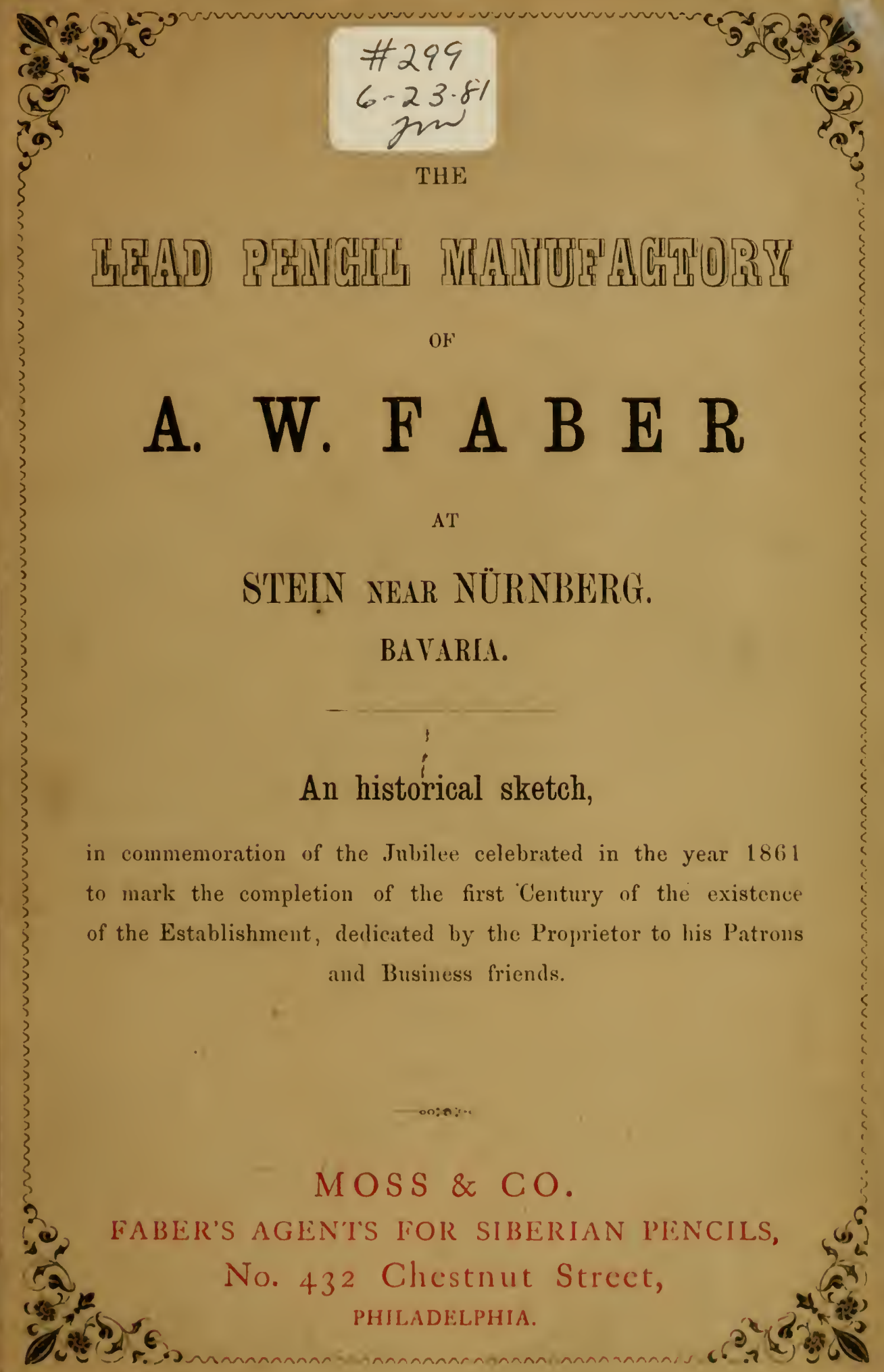





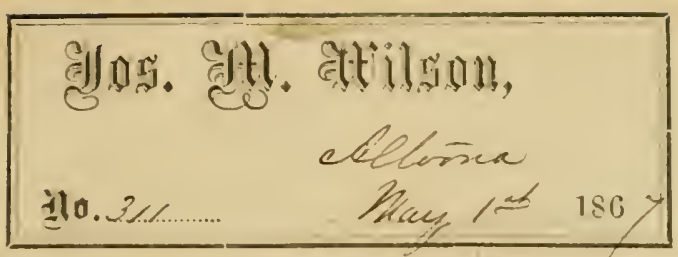

DESCRIPTIVE LIST

of

FABER'S SIBERIAN LEAD PENCILS, (S:e page :20 to:23 inclusive.)

ESPECIALLY ADAPTEI)

For Exgineers, Architects, Artists, Wood Engravers, and

Office Use.

\begin{tabular}{|c|c|c|}
\hline $\begin{array}{l}\text { Extra Soft and Extra Black, } \\
\text { Very Soft and Very Black, }\end{array}$ & marked & $\begin{array}{l}\text { B B B B B B } \\
\text { B B B }\end{array}$ \\
\hline Soft and Very Black, & “ & B B or No. 1 . \\
\hline Soft and Black, & “ & "No. 2 . \\
\hline Hard and Black, & “ & H 13 “ No. 3. \\
\hline Middling, & “ & “ No. 4 . \\
\hline Hard, & “ & II “ No. 5. \\
\hline Harder, & " & II II \\
\hline Very II ard, & “ & II II H \\
\hline Extra Hard, & “6 & Н Н II Н II H \\
\hline
\end{tabular}

On cards, to pencils, one of each above grades.

In boxcs, 7 do. do. do. B B B, B I3, B, II H, F, II, II H.

Do. ; do. do. do. B B, B, II B, I, H.

Do. $;$ initil kxifzasdrumber.) do. do. do. do. do.

Artists' Patent Pencils with moveable leads of all the grades.

Moreable leads, same quality, in boxes, containing six leads of any grade.

\section{MOSS \& CO.}

Dealers in Drawing Instruments, Papers, Tracing Cloth, Tracing Paper, \&rc.

No. 432 Chestiut Street,

PHILADELPHIA. 



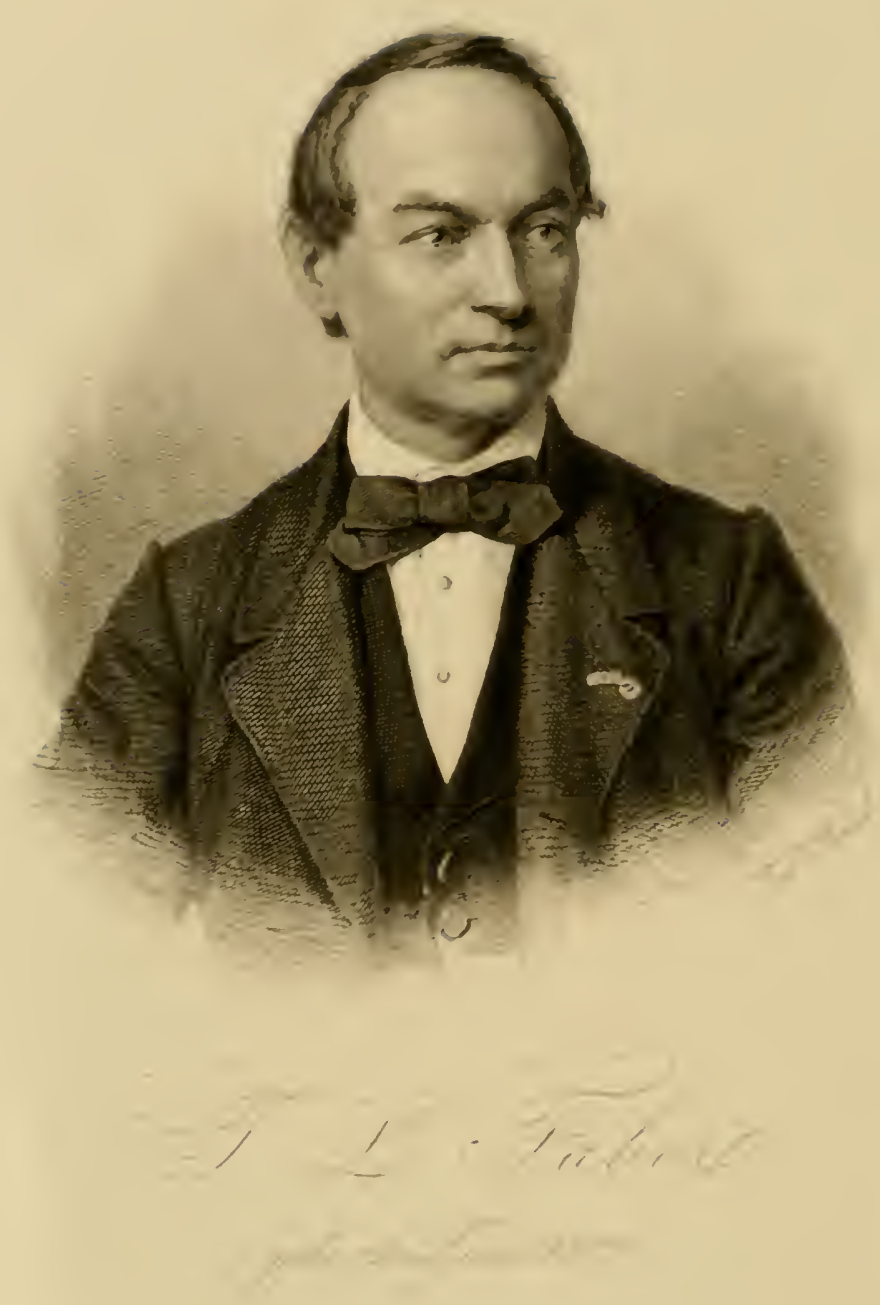


THE

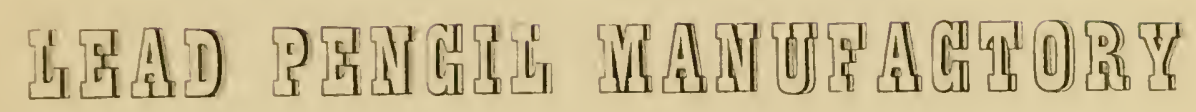
$\mathrm{OF}$

\section{A. W. F A B E R}

$\mathrm{AT}$

\section{STENN NEAR NÜRNBERG.} BAVARIA.

\section{An historical sketch,}

in commemoration of the Jubilee celebrated in the year 1861 to mark the completion of the first Century of the existence of the Establishment, dedicated by the Proprietor to his Patrons and Business friends. 

unhesitatingly he placed side ly side with the numerons improsements and imentions, by means of which the last three centuries in particular have so larely contrihuted towarls the spread of Arts and Sciences and the facilitation of Study and Communication. To the elassic ages and their art the pencil and in general every application of lead as a writing material was cutirely unlinown and it was first in the midlle ages, as we hear, that lead was employed for this purpose. This metal howerer was by no means the same sort of thing as the black learl of our pencils, which are indeed only mentioned in conjunction of lead on account of the writing produced by them hearing some resemblanee to lead. Besides which lead was then only used for ruling lines and in no instance for writing or drawing purposes. This leadruler was in form a shampentered dise. such as is sail to have lieen used for the same purpose even in the later periods of the classic ages.

With the derelopement and growth of modern painting the traces of pencil-like drawings first hegin to manifest themaldes. The masters of the fourtecnth century, ecpeeially van Eyelk, and of the fiftecnth, such as Mrmlink and others, apjear in be the first when mention worlis of art executod with a pencil-like instrument upon chatlied paper. They are generally desimnated as

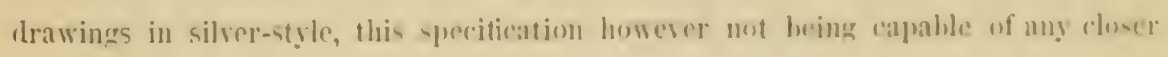


confirmation, though this much is certain that the use of pure silver is not intended to be implied. In like mamer it is reported of the ltalian artists of the latter part of the midile ages, that they drew with a silver-style upon smooth deal covered with the dust of ealeined bones, which process appears however only to have met with very partial suceess.

On the other hand in Italy in the fourteenth century moch drawing was done with styles composed of a mixture of leall and tin; lrawings that could be efiaced with bread crmmb.

Petraleh's Lama was delineated by a contemporary in this mamer and in the time of II ichael Angelo the process was still in use. These styles were then introduced into Germany from Italy, under what partieular name, we know not. In Italy they are ealled "Stile", but even they nerer seem at any" time to lave been the miversally acknowledged drawing material.

About the same period the pen came into use as a lrawing- as well at writing-material, to which were added, in the most flourishing days of painting, black chalk and red clalk which enjoyed extensive use. The Italians ubtained the best red clialk from Germany and the best black clalk from spain. Vasari, speaking of an artist of the sixteenth century, especially remarks that he mulerstood how to use style, pen, black chalk and red chalk with equal dexterity.

To this period belongs also the discovery of black leal and with it the production of an entirely new writing - and drawing-material - The Lead Pencil.

This invention, which conferred so many bencfits not only upon practical life but also upon art, was made in England in the reign of Queen Elisaleth, for in the year 1564 the celebrated hlacklead mines of Borrowdale in Cumberland were discovered. With the opening of this mine erery element was present to render the developement of an extensive pencil trate upon English soil poscible.

In the year 1565 the first lead pencils were mauntactured in England. The mines of Borrowdale, at one time on account of the valuable uature of their produce exposed even to the predatory attaclis of the inhabitanta of the neighbonring mountains, supply the English down to the present day with the material 
for the hest English leadpencils. The manufacturing of the lead obtained was simple, the material, as soon as it came out of the mine, being cut to the proper size with a saw and then without any further manipulation fastened into the wood and it is remarkable, that the first pencils made in this manner are acknowledged to be decidedy the hest and down to the present day unsurpassed by any other mamufacture in the softness and clelicacy of the lead. Although the Cumberland peneils were soon in great request as being the first to really meet an exigeney long felt, it is their excellent quality that has given them their lasting and universal reputation especially in the World of Art.

The Cumberland mine only remained open for six weelis in the year and get the blacklead olotained in this short time is stated to have heen of the ralue of $£ 40,000$ or One Million Franes each time.

The raw material was sent up to London just as it eame from the mine and there sold hy auction in the hack lead market, these sales taking place on the first Monday in every month. The price averaged $36-40$ shillings per English pound and the value of the good Cumberland black lead aceording to Dufrénoy was 400 Francs per Kilogramme.

The fact of the English frovernment laving considered it expeclient rigorously to prohibit the export of hlack lead in any other form than that of leadpencils goes to prove of what importance these mines and the mannfacture of leadpencils in connexion with them was to England. In spite of the fact however that the mines only remained open for six weeks in the rear and that no hlacklead might be exported from them, the working of the mines, continued as it was for upwards of a century, at last began to have the effect of diminishing the jield, until at last nothing was to be obtained from them lout an inferior and impure material no longer adajted as before for the manufacture of pencils.

In order to protect themselves from the consequences of a failure of the Cumberland hlacklead mincs, the Engrlish strenuonsly sought in everg direction 
for new blacklead deposits, but down to the present day without the de-ired snccess. There remained therefore nothing but to look about for some means wherely the impure refuse still ohtainable conld be pruritient.

The process invented for this purpose consinted of tirst grinling the blackleal to powiler as soon as it eame out of the minr, then purifying it as much as posible from foreign substanes by chemieal means and tinally compressing it by means of a press in such a maner that the ma-s could be ju-t as easily cut as the pure Cumberlaud lilacklead used to be. IIowerer notwithatamding all the appliances of art and scienee were brought to bear upon the sulgeet and spite of every exertion to render this composition perteet, the English have not litherto sneceeded in producing any material eaprable of repliteing the matural hlacklead as olitained from the Cumberland mines.

These cireminstances operatel as an inducement to search for a substitute, which wonld admit of a sreater ceonnmy in the use of hickleal. Experimente were made in Englant with this view and various sulstances smels as glue, jsinglass, tragaeanth, gum ife. were tried for the purpose of cementing and consolidating the cartlyy blacklead into a firm mass. But none of these means sncceeded. Subsequently it was attenupted to improve the blacklearl by melting it with minerals, compounling it with 30 or $40 \mathrm{per}$ cent of sulphulu. But this marle the blacklead too brittle and the pencils made by this process would hardly mark at all. At last mixing with antimony was tried, whirh certainly yicledel a composition in outward appearance very similar to the pure blacklead, but which proved to be but an unsatisfactory writingmaterial.

Towards the end of last ecutury the manufacture of leadpencils was introduced into France aul soon attained to an extensive developement. Ilardly were the last restrictions upon industrial freelom removed in that country, when in the year 1795 the idea was started of making use of clay for the purpose of binding the blackleal together. This process soon found favor on account of its many advantages for hy this commixture a great portion of the costly blacklearl 
was saved and at the same time the manufacture rendered materially easier, so that the leadpencils conll be supplierl at a very much clieaper rate.

By these novel improvements a fresh era in the manufactme of learpencils was commenced in France. Notwithstanding this however, there was yet very much to be done in the department of hlaclileadpencil manufacture in order to keep pace with the increased requirements of alvancing art and more civilised life.

True, various degrees of lariness and different sorts of pencils were thus obtained but these were by no means proportional to the various modes of use. The manipulation of the brittle material demanded deep study, and conscientious laborers in order to give the pencil the requisite perfection.

If we now turu to Germany, it will in the first place be necessary to east a glance at the developement of Gernan industry and German leadpencil mannfacture, it being then shown under what circumstances it hat to levelope itself and with what rivals it had to enter into competition.

It is not to be denied that from the rery first Germun industry found itself in a more disadvantageous position. France and England harl alrealy become intrinsically industrious comntries. They possessed immense facilities for foreign tratle, the greatest internal freedom of motion for the industrial element, a legislature which tooli cognizance of all the reguirements of industry, in short both countries were, in comparison with Germany, fivored ly certain circumstances which are indispensally necessary to render iudustry Hourishing and which were then already fulfilled, whereas in Germany political division and amimosity and the pressure of the guilds operated most pernicionsly unum industrial entreprise.

For these reasons industry could only develope itsedf in Germany later and then but showly. 'The transition from the old to the new state of thinge appeared much more difficult, as many long since antipuated forms, which hatd become endeared to us hy usce, hat tirst to be abolisherl.

The Saxon spirit, which, on the other side of the ('hammel hat attained to such glorions results, haul to sustain many al contlict in its native land, and 
many a praiseworthy attempt suffered shipwreck on the many obstacles, which the splitting up of the nation and the retention of unfeasable arrangements opplosed to erery great idleat.

(ierman science flourished at the sime time to a very great extent, but in its exaltation it stood too high ahove ordinary life, not perceiving how to associate itself with it, sn as to penetrate it with its enlightening and warmtheiving rays. Thus German industry remained far behind forcign enterprise and (iermany beheld hersedf inundated with quantities of foreign mannfactures, which she herself conld have prodnced just as well, indeed it came to such a pass that foreigners relying npon their well organised commerce and the celebrity of their products even ventured to semt (ierman manufactures into the frermau market, stamped with a foreign trademark.

(ierman industry being at this low ebb, the manufacture of leadpencils occupied lut a very modest place. The first traces are to be found in the village of stein not far from $\mathrm{N}$ in ruberg. As far back as the year liz2t the churchboolis mention marriages of "Peneilmakers", sulsequently also "Blacklead cutters" male and female.

Ioadpencil making however was then in its very lowest state, as in 110 case is a large establishment mentioned, and it may be assumed that this branch of trade was only just able to maintain a precarions position in comparison with the Einglish manufacture.

The Bararian govermment however soon devoted their attention to this branch of industry and sought to advance it. In the year 1766 a Count ron Kronsfeld received a concession for the erection of a leadjencil manufactory at Jettenbacl.

But the manufacture, wanting as it was in material, experience and custom, still remained so insignificant, that in "I3eckmanns Technologie", which appeared in the year 1777 "Pencilmaking" merely reccived a quite superficial and incidental notice. 


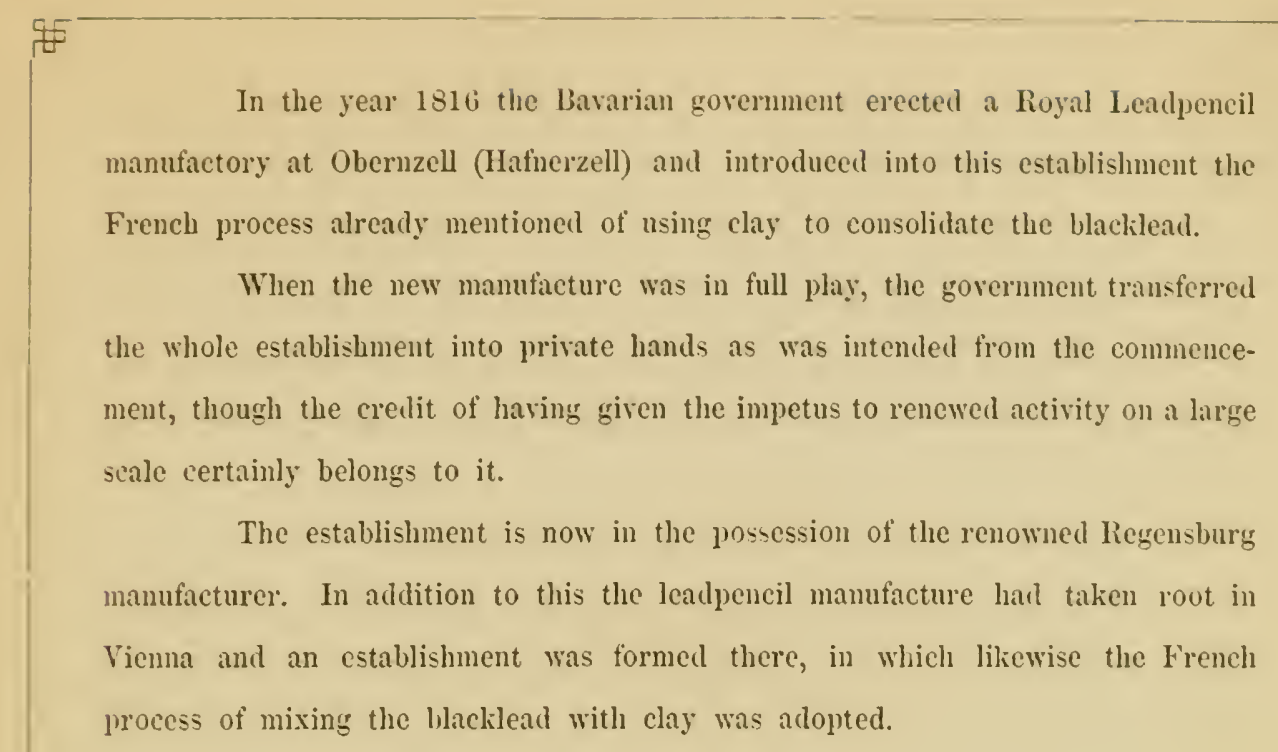

In the year 1816 the Bavarian government erected a Royal Leadpencil the French process already mentioned of using clay to consolidate the blacklead.

When the new manufacture was in full play, the government transferred the whole establishment into private hands as was intended from the commencement, though the eretit of hasing given the impetus to renewer activity on a large seale certainly belongs to it.

The establishment is now in the possession of the renowned Regensburg mamucturer. In addition to this the leadpencil manufacture lar taken root in Vienna and an ostablishment was formert there, in which tikowse the French process of mixing the blacklead with clay was adopted.

The now so extensive leadpencil manufactory at Stein sprung from very modest begimings. In the year 1760 namely its founder, Kasplur Faber, settled in this village of Stein three miles from Nüruberg, and in the year 1761 commenced the manufacture of leadpeneils.

At that time adverse extermal circumstances pressed heavily upon the young manufactory, the whole possessions of its founder consisting only of a small house situated on the Reduitz and surrounded by a small garden. A judicial inventory dated 1786 still preserver in the family specifies faithfully the insignifieant property possessed by them, showing a nett result of "Fifty nine thorins".

The finest and dearest qualities mentioned therein are spolien of as nseveral gross of English pencils“, for thus the better German manufactures hat to disguise themselves under a foreign title. The demand for these manufictures was trifling and purely local, as the spirit of commerce and enterprise did but little to assist their introduction.

Nurnberg and Firrth aplear to have been the first to patronise the froducts of the mannfactory. To these places, as we know, the pencils finished in the course of the week were carried on Saturdays in a basket; hut the fact of their having been well paid for goes to prove that even then their excellenen 
was ackonwedied. The relations at that time exi-ting between the producer and the comsuming public wre however lout litte regulated. The producer stood by himself alone, rut off from the world, which seemed to him too immensely large for him to dare to sep out into it. The farsighted vision, searehing in (every direction to discover new wants and insent new improvements. were wanting to lim, as was aloo the bencticial influence of external relations, with which lo was never hrought in contact.

Nor was the consumer any more favorably situated.

The article hecame the object of extensive commercial speculation and hard often to travel a very long way before it reached the hamd of the cunsuming fublic, nor was the repute of a good name any guarantec to the consumer of the excellence of the article, for in oriler to keep the manufacturers in complete dependance, the merchants would not allow them to mark their hetter products with their names, but prescribed them foreign mames and umeaning signs, such as: Harpe, Stars etc.

It was but slowly that the French process of mixing the lead with clay gained gromel and many years after the adoption of this process the workmen, even in F'aber's manufactory, were still employed it working the Spanish lead in the old fashioned way hy melting it and cutting it with a saw.

The progress of the French however soon forced the merchants to prest the Niirnberg manfacturers to advance, so as not to be left behinel by competition. After the introduction of the new composition the Nimberg manufactories soon found themselves farorably circumstanced and yielded satisfactory profits both to the merchants and the manufacturers.

But this was not to last. In the first ten years of this century competition increased steadily and enormonsly so that demand by no means kept pace with supply, and the vital question forced itself upon the manufacturers, whether they were in a position to produce the artich cither better or cheaper?

This diffient problem was however solved in a manner unfavorable to 


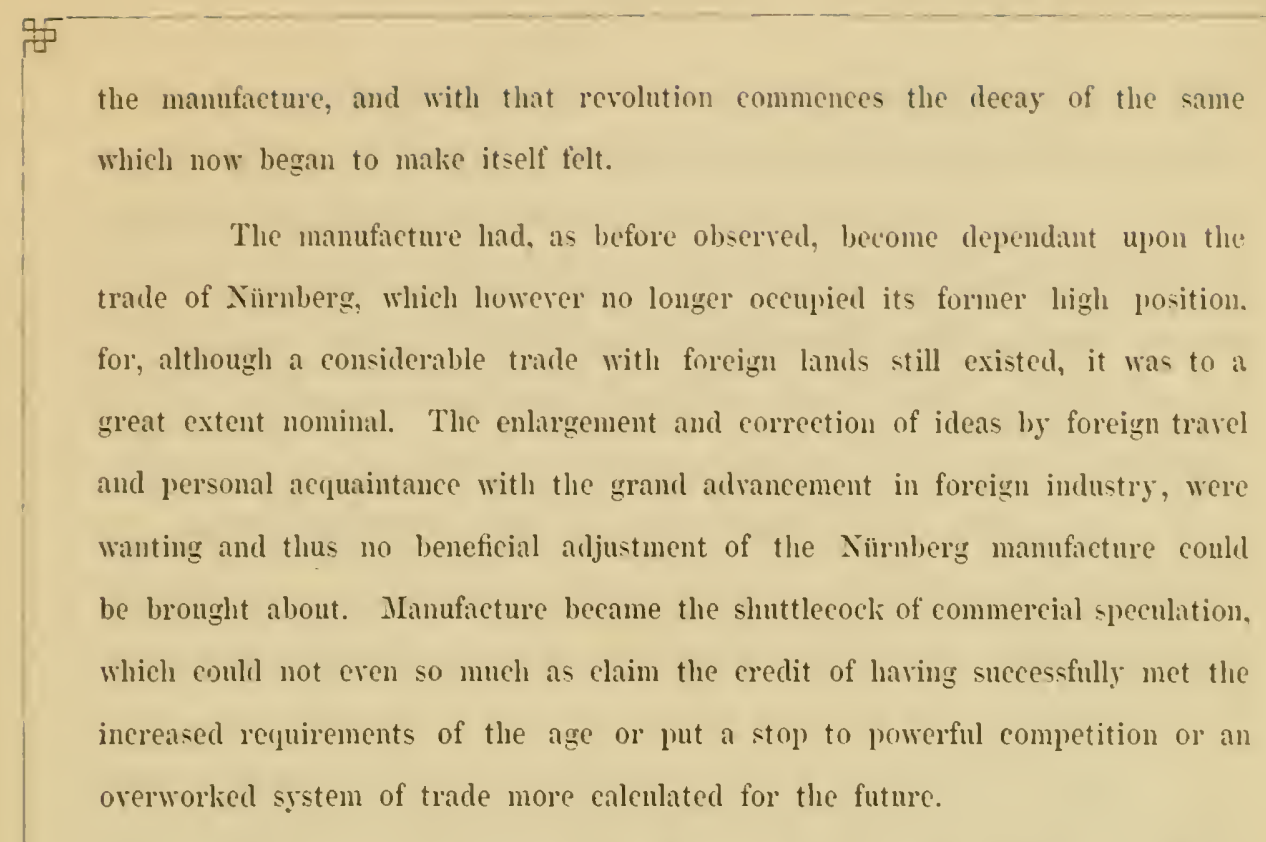

The trade of Nüruberg at that time lay in the fetter's of the gruild strstem, the relic of an earlier golden time, which, aiming at the isolation of industry, which was thereby given into its hands, was the ban that opposed its progress for a length of time, alluring it to act contrary to the interests of native industry and therefore contrary to its own interests.

How much did this system leave of the ancient splendor and well earnt renown of the City of Nürnberg? - $\Lambda$ minimum kept and retaned solely and alone by the self denial, frugality and industry of the inhalbitants. The ingenious, serviceable articles had disappeared, giving place to goods, whose only recommendation consisted in their being unprecedentedly cheap. The endearour to manufacture without the least regard to guality or serviceability as long as cheapness was attained har become a ronted evil increasing as it descended in all its fulness from father to son. The lonorable distinction of the title "Nuernberg, good" soon became changed into the lasting and contemptuons one of "Nornberg goods" and in the business world people eren went so far an to say that nothing gorod coulil possilly be produced at Nibruberg. 
These circumstances, which are to be laisl to the acrome not only of individuals but likewise of a dominecring syetem and the spirit of a time not sn very far di-tant even now, atte-t that real industrial activity mus go hand in hand with mereantile spirit in order to maintain itolf in the world free from the intluences ahove puintel ont and enter the lists with competition. It is only emancipated industry that can consratulate itsolf on real progrus and improve the article nuly by having an pye to the requirements of the consumer.

It was under these circumstances that Inton Wilhelu Faber, the son of the founder, whose name the firm -till bears, and siace 1810 (ieoly Leonhard Faber, the father of the present proprietor, sood at the heal of the establi-hment.

Many impruvements had been attempted and several andopted; imuch valuable experience had been gained, many proceses in the manufacture had been perfected and a number of intelligent workmen drawn together; spite of all this however the mercantile relations above deseribed operated mo-t pernicionsly upon the manufactory.

The morle of manufacture induced by the enslavement of industry on the part of trade more especially destroyed that conscientious strictnes, which must form the foundation of a solid industry. Thinge went so far that articles were sent forth into the worlul, posessing the outward appearance of pencils, the wood being just tiplped with lead at each end as though it was properly filled, whereas in fact you only harl a useless stick of woor before you.

Such swinulling imposition:, sent forth by the Nürubery inanufactories into foreign countries, were well calculated to bring abont a complete collapse and it is difficult to regain confidence once deceived or exteem once forfeited. But it must not be cupposed that the interests of the Nibrnherg pencil manufacture were not solid. The unscrupulous transactions on part of some establishments as a matter of course damaged the reputation of those which carried on their business in an industrious and conscientions manner and the renown of the whole trade was thus placed in jeopardy. 
In the year 1839 the present proprietor Johann Lothar Faber

undertook the management of the manufuetory upon the death of his father Georg Leouhard F'aber ahorenamed.

This gentleman had, down to hiv nineteenth year, endeavoured as far as possible to perfect his commereial education in Nuernberg in the most fundilmental and general mamner and. from his earliest youth, especially devoted himself to the study of ererything at all hearing upon his father's mannfactory. Even at that time he directed his attention not merely to his finther's aftiars, but also to the developement of a husiness so sadly erippled and underwent many privations in order as much qs possible to satisfy the manifold elaims laid upon him hy the aim which was always present to his imagination.

When nineteen year's of age he went to Paris in order to increave his stock of knowledge. There, in that eapital of the World a greater range of vision was opened to lim and he beheld the operation of that restless spirit of enterprise, which so miglitily stin's the heart of the country. For the first time the youth was bronglit face to face with the enormous business carried on hoth with France and foreign lands and of which Paris is the eentre. Ile surveged the fruits of a fiee, active industry, the great highroads, upon which commerce flows from the mother country to distant lands, the realisation of a colossil traffic, which allows no article to escape its observation and flows in an ever moving wave between purehasers and consumers. Then his thought were earried back to his distant native land with its industry so cramped and fettered as to be altogether estranged from the great markets of the world and the possibility flashed across his mind, that matters might be rendered very different at home and native industry not only recongner its honour and the renown of its pristine good name, hut that it minht also he lod forth from its narrow prison and enabled to compete with the vigone and intelligence of the markets of the world and that it wonld thu- cusure obtaining an homourable porition.

At that time industrial life was in full activity at l'arie, scarrely 
six years having clapsed since the revolution of July and I.nuis Philippe heing firmly establi-hed on the constitutional citizen-throne.

Thus freat hopes filled the breat of the gommg man and impelled him to follow up the ideas and plaus of life he harl adopted with all his energy:

After a sojomrn of three years in l'aris there foll uyon him suldenly and mexpectedly, on the misht of his labours, the news of the death of his fatler and after first performing a previonsly contemplated journey to London, in order to enrich his store of knowledge and experienee, he returued to his mative lamd in August 1839.

Now was the time to carry ont and realise all the ideans he had imbibed. The comlition of his father's manufactory wat, as before statid, extremely misttisfactory. Scarcely twenty workmen were employed and the ammal business tone amounted only to about 12000 florins. If that glorions future, which the young man harl assigned to the manufactory in his imagination at l'aris was to become a fact, it would imolve carrying on a conflict with all the old perverted notions, to break with the cumbersome progress of former times and upon the ruins of the Nümberg trade, which belseld itself excluded from the world's market, to lay the foundations of a new commeree, which alone would be able to recompuer for the venerable commercial city of Nimberg her ancient renown.

He was the man, who brought, in the first place certainly only the pencil manufacture, but therewith also native industry in general, into direct contact with the ideas of forcign comntries.

Sure and gradual progress was however indispensable. The new proprictor alopted the llevice of:

$$
\text { "Truth, Respectability, Industry" }
$$

as the fundamental principle of his dealings, being firmly convinced, that no human undertaking, which aspires to a future and lasting success, can possibly exist, if it in any respect be based upon untruth, or at variance with that, which passes for right and respectable among men in general or, which ignores the duty of unwearying activity and energetic industry. These principles sermed to 
lim all the more indispensable for his manufactory as he, by his position, rendered himself to a certain extent responsible for the weal and woe of so many couls.

The two brothers of the new proprietor had been destined by their father for other modes of ocempation, there being at that time no prospect of the pencil mannfacture maintaining them.

The present proprietor of the manufactory however, feeling contident of the success of his comprehensive schemes, took to himself in the year 1840 his second youngest brother Johann Faiver, who at that time carricd on an Ifotel at Prague, in order to unite his activity with his own.

The pencils were then only manufactureal in proportionally few and cheall sorts, but the new proprietor of the manufactory was soon induced to introduce finer sorts at proportionate prices.

While still at Paris he had endeavoured in every way by letters to his father to conduce towards the elevation of the manufactory and the improvement of the rquality of the articles manufactured, but it was when he began to put lis hands to the work himself that he first amed at any material success.

These improved mannfactures and especially his new so ealled Polvgrate P'eneils, which have met with the greatest renown especially among artists, were all marked with the name of the firm and, as they by reason of their increased price. the mavoidable consequence of improved yuality, met with but little comtenauce among the Nürnberg merchants, the mantacturer travelled with them himself through Germany, Rusia, Anstria, Belgimm, Holland, France, England, Italy and switzerlant and opened up business comnexions with all the ehief eitjes of Europe, which, with the contimed improvements in his mantactures, coun found him a satisfictory custom and an ever increasing demand, jumprtant enough to raise itsclf ahove the narrow spllere of local interests.

In the interior of the mamufictory too great improvenents were mulertaken, as nearly every year callerl for some new adhition. In thene new eresetions rare was taken to comstruct them as roomy and light as pos-ible, thus 
talking inte con-ideration the health of the workmen and the fact that work

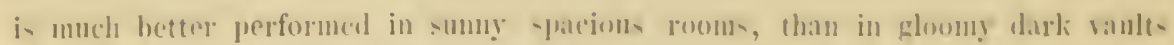
in which the air cannet he renewerl. and that the plea-nere and /est with which

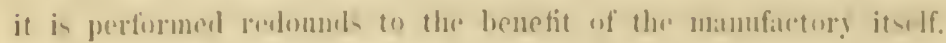

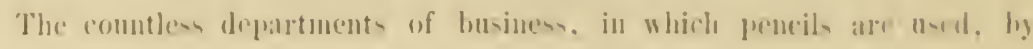

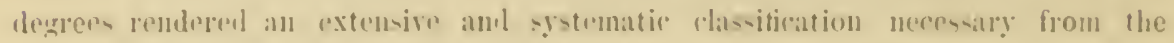

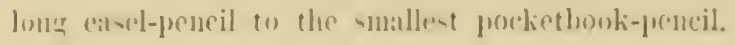

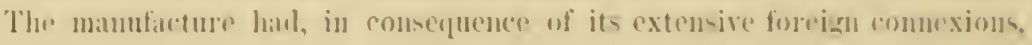

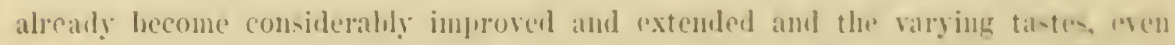
the varying enutous of the nations which used them, had to be talien into consiloration. The manuficturer never ceased to stuly all wants, to suliject his manutictures comstantly to new trials, to arail himedf of fresh experience in order to surpan with his product all similar articles il powible.

The renown of his manufactures has penetrated to all parts of the word and it is not merely their widely extended use, that attest their exrellence. hut more especially the roice of those men, who make the greatest demank upon the mannfactory. There are few Arehitects and Eneineers who use any other article but Faber's pencils, and the whole profersion of arti-t has long since proclaimed A. W. Faber's pencil to be the very best for drawing pur-

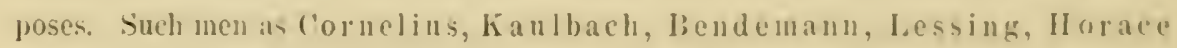
Vermet have expresond themselves to this effect.

In accordance with this rerdict is the result of the competition in the several industrial Exhibitions, both at home and abroad, in which Faber's pencils gained the victory wer all other manufactures of the same nature.

With the year 184 ! a new era in the actirity of the mannfactory commeneed. Ever since that year the products of the manufactory lad met with recognition and custom in Aneriea and with the continucl increase of the population it was to he assumed that the sale of the sane would alot comstantly increase in inportance, especially as the manufarture of Jealperurile haul not at 
yet taken firm root there and it therefore became a yuestion of obtaining a generally ackinowledged product of European manufacture, the cxcellence of which Inad been proved by the experience of years and its honest mamfacture.

This inluced the proprietor of the manufactory to establish a honse at Yew-York aud entrust the management of the same to his youngest brother Eherhard Faber, who had just completed his study for the law at the univer-ities of Berlin and Erlangen and was at that time engaged in acquiring the nece-sary mercantile knowledge in the establishment at Stein.

The trade with America thereby acquired a firm footing, the communication spite of the great distance became more regular and the comnexion of the manufictory with the new world more close. As England, France, Russia, Italy and the East had long since been open to Faber's manufictures, the idea of creating an miversal trade appeared to be realised.

As in the American commercial metropolis, so also in Paris a house was founded, not merely to manage the important trarle with France and the neirhbouring countries, but also to minister to the fine tastes and elegant reunirements of the French, which are of so much advantage to any product intrinsically excellent.

In like mamer, in order to supply the requirements of England, India and $\mathrm{A}$ ustralia, an agency was established in London in the year 1851 with Ir. A. Heintzmann, now Heintzmann \& Rochussen, of No ! Fridly Street, City; E. C.

While thus the external relations of the manufactory contimued steadily to extend themselves, its internal developement likewise ardvanced step by itep.

On the very spot, where once the little house stood, the extensive factory premises are now erected on either side of the Rednity, the water jower of which river proving ton insufficient and fluctuatiug, steam had to be ealled into requicition and a large engine crested.

As already stated, almost each year demanded an aldition to the premises and consillerable enlargements and alterations rembered necesary bartly 
by the constantly inereasing business and partly by sanatory or crmanental considerations, so that the very eharacter of the locality underwent considerable change.

(iardens now enclose the whole establi-liment on three of its sides. In one of them stands the residence of the proprietor of the mannfactors, Lothar. visible from afar ly reason of the height of its situation and remarkible on aceomt of the peculiarity of the style of its architecture: in the other the house of his younger brother, Johann, so that everything stands together in the closest connexion like the life of a large fimnily.

The proprietor, while endeavouring in every way to advance all the ends of the mamfactory in the most perfeet manner, has not omitted to bear in mind at the same time the moral and material welfure of his wolkmen, whom he has aceustomed himself to recognise as men and his fellow creatures.

In their interest there were in the first place factory rules drawn up. which regulated the duties and rights of the indiridual in the most preeise manner and especially took cognisance of the moral conduct of the workman. They also gave the most diligent workmen and such ats were more alvanced in years, opportunities of inereasing their income hy ensuring them an increase of pay under certain conditions.

In order to awaken and encourage a spirit of frugality in the men and to reuder their future more comfortable and independant, a Workman's Sarings Bank was instituted, with the following fundamental principles: Aeceptance of the smallest deposit at-any time; interest at four per cent to commence as soon as the deposit reaches the amount of fire florins; deposits to be withdrawn only on account of some notoriously pressing necessity. 'This institution found immediate recognition and by degrees came into almost general favor, so that now many an individual, who formerly had to battle with economical cares, finds himself in the possession of a little property and rejoices in his wellregulated family affairs.

There is likewise a special fund for sickness.

A library has also been founded by the master of the manufactory, 
accessible both to the workman and his family and well used by them, at the
same time too an infant school was started for the children of the work people. He likewise originated and supported with his own means the erection of a new schoolhouse, and embraced every opportunity of advaneing the elucation therein.

The social life of the workmen was also taken into consideration and the taste for more elerating amusements, invigorating alike to soul anr body, encouraged. Of an evening they would meet in two singing societies to indulge in the good fierman song, or on Sundays they would amnse themselves with the crossbow in the free, fresh air of God's Nature in the neighbouring forest, or again on festive oceasions they wonld all meet together like one large united family for a sociable convivial repast.

Finally, care was also taken that the workman shonkl mix with the world outside the factory; for which purpose a number of them were sent by the master of the factory to the Industrial Exhibition at Munich in order that they might themselves see the fruit of their labour publicly exposed to view and honorably mentioned, and at the same time obtain a glimpse of other branches of industry.

Further, in order to provide new dwellings for the workmun a large building was erected, of pleasing external proportions, and other buildings were converted into workmen's dwellings. The houses themselves contain separate apartments, which afturd the families at a low rent a much pleasanter abode than contd be obtained in most of the houses in the towns. Nor is there any constraint; the louses are open to any body and the clomestic regulations introduced in the interests of the community are of that mature, that they are cheerfully complied with by everyone. 'llus there reigns in these premises a spirit of order and contentment, which alone can make life agrecalle.

The village of stein dis not formerly possess any churh. lor year all exertions to found a separate parish there remained fruitless, until at last thr year 1861 brought their reward and in that year, in which the manufuctory celebrated its lomidredth amiversary, the peaceful clang of the bells for the tirst time 
invited the faithful to divine service in the newly erected clunch, the cost of which hatd heen defrayed by the master of the factory entirely from his own means, ont of concern for the spiritual welfare of his workpeople and attachnent to his own native place.

The formerly meglected little village has assmmed quite a different appearance since then. From afar the slender gothic streple of the clunrch may be seen rearing its pinnacle proully aloft, while the smoke of the surrounding shafts tell of buy industry ausl labour. The former picture of want has given place (1) a certain denree of wealth and the little garden of the humble house been converted into two large parks.

Simultaneonsly however with this prosperity in general the manufactory hal of course to experience some muleasant incidents and ob-tinate strugreles. The unirersal lemand for Faber's manufactures was not slow in inducing other manufacturers to imitate and pirate the trademark of the manufactory, which is to be found on all articles manufactured there, and thus to pass off upon the public spurious goods possessing nothing more than the external similarity to the genuine articles, and which could scarcely aspire to medincrity, which frauds were often repeated, coming to light in various countries.

The manufacturing firm of Rubenstein at Moscow adopted the plan of making use of Faber's trademark and wrappers for their own mannfactures and then to circulate then in the Rusian market. These malpractises were carried on for a length of time in spite of every exertion to put a stop to them and the prohbition which the lussian Governement issued against the firm in question. Manufactures with spurious trademarks were constantly turning up in Russia until King II aximilian of Bavaria luring his protracted stay at Nornberg in the year 1855 suppressed the evil. His lively interest for reviviur industry had already inducerl him to decorate the proprietor of the manufactory with the order of merit of St. Michael, firstclass, in the year 1854, on which occasion he likewise homoured the factory at Stein with a visit and marle himself acruainted with all the details of its operations from the mouth of the manager 
of the factory, and as at that time these malpractises were brought before his notice he gave the matter all his attention and promised some assistance.

Nor had we to wait long for this, for slortly afterwards Lothar F a ber received a comnunication from the State ministry of the Royal House and Foreign affairs, stating, that, by the interrention of the Royal Bavarian Embassy at St. Petersburg, the evil had been put a stop to by the Rinssian Government; all the articles marked with Faber's trademark together with the stamp destroyed, and the manager of the Russian manufactory compelled to give assurance in writing that he would no longer pirate Faber's trademark, in default rendering himself liable to legal penalties.

In New-York similar frauds were also carried on. Pencils manufactured in Nürnberg with Faber's trademark and in precise imitations of lis wrippers were imported and sold by the firm of Winterhofi, Piper $\& \mathrm{C}^{\circ}$. Complaint having been made, the Customhouse at New-York, at the instance of the examiner appointed for the department of "Literature, Writingmaterials and fine Arts". detained one case of these spurious articles, whereupon the courts of law prohibited all further sale in the town and county of New-York.

A still more cumning frand was perpetrated at Nürnberg. A deaf and dumb lithographer by name Georg Wolfgang Faber was put forward, whose name was to be made use of. The similarity of the surname and wrapper exactly copied from those of Faber's manufactory were sufficient to make the public believe that they really had the genuine article from Faber's manufactory before them. On the intervention of the authorities, whom Lothar Faber put in motion, the reputed manufacturer was subjected to an examination, which proved him to be altogether ineapable of producing such a thing as a serviceable article and shewerl that he had only lent his name to other speculators, whereupon the Royal Government of mildle Franeonia withdrew the lieence for pencil making from the sail (i. W. liaber.

Procedings were likewise taken against a Pencilmanufacturer at Fulda, who had manufactured and circulated upwards of seven thousind dozen learl- 
pencils with the false stamp "A. W. Faber". The Criminal Court of the lilectorate of Hesse in a decision dated 2nd September 185ti, comdenmed the defendant, on account of framl, to al jecuniary tine of 50 Thaless and further to four weelis imprisomment, a decision, which the supreme Court of Appeal at Cansel alsolutely contirmed. Similar events took place in other countries with like results.

As the proprictor of the factory has hitherto proceeded against many persons at home and abroal who had attempted to manufacture and sell pencils in imitation of those of his firm he will further use all his efiorts to suppress every deception foisted upon the public.

In the meanwhile the manufactory assiduously endeavoured to attain to perfection in its products. As the stock of blacklead began to disilupear in the mines of Cumberland, it succeeded, by its perfected manipulation of the material, in producing so many grades of hardness and supplying such an extensire variety of pencil, that no demand conld present itself without meeting with sutisfaction among the great choice of manufactures.

In the opinion of connoisseurs the finest sorts even surpass the best Cumberland leadpencils in their lasting and uniform degrees of hardness, their greater firmmess and durability as also in the increased purity of the lead. In addition to this they possess such an amount of softness and delicacy, as to be able to stand comparison in this and crery particular with the Cumberland pencils. Besides this, and in addition to several other improvements relating to their external appearance, the most useful and ornamental shapes for pencils of the finer descriptions were derised and introduced, and still more recently the socalled "Artist's pencils" were added to the list of novelties and immediately. met with the most universal recognition, which soon stimulated other manufacturers to attempt imitations.

In the midst of these exertions the news was sudlenly received, that that, which the English had so long sought for and which the perfected system of manufacture still stood much in need of in order to yield more than was 
previously possible, had been found. A new blackleat mine had been diseovered. Johann Peter Alibert, merchant of the first class at Tabasthus in Siberia, had undertaken an exploring expedition in the mountainous eastern portion of Sibcria, partly to search for goll. He examined the sand of the rivers Okil, Belloi, litoi and Irkutsk, and in one of the mountain ravines in the vicinity of Irkutsk lighted accidentally upon specimens of pure blacklcad. Alibert immediately recognised the value and importance of the material and instituted strict inrestigations until in the year 1847 after much labor and exertion he arrived at the conviction that, in a branch of the momtain range of Saian among the heights of the Batongol mountains four humbed versts westward of the town of Irkutsk, close to the frontier of China, a primitive deposit of blacklead must exist. He addressed himself at once to the task of opening a mine in order to bring the costly material to the surface.

At first the blacklead met with provel to be no better than the refuse Cumberland blacklead, and upwards of three hundred tons of this quality had to be removed before a deposit of the best and purest blacklead was finally opened up. Pieces were soon oltained weighingr as much as cighty pounds. The Academy of Sciences at St. Petersburg, before which body Alibert lail lis samples of blacklead for analysis, declared the same to consist of the same elements and possess the same properties and consequently to be of precisely the same nature as the Cumberland blacklear. Alibert now procected to England where he visited the declining blacklearl mines of Cumberland and convineed himself by personal observation of the exhaustion and llecay of the same. He thereupon submitted his samples of blacklearl to some of the most extensive English leadpencil manufactories for examination, who maminously confirmed the verdict of the Acatemy at St. Petersburg, pronomeing the quality of the Siberian blacklead to be excellent and in no way inferior to the Cumberland land.

It had cost Alibert eight years of mmemitting lahour and a capital of one million Franes when he beheld his enterprise crowned with this certainly unexpected success. 
He now turned lis attention to rendering the newly discovered material available for the mannfacture of pencils. Having convinced himself that liaber's manufactory was the most extensive in existence and that it circulated the largest amount of fine goods in the world, he applied to the same with a proposition for an agreement, by virtue of which his blacklead was to be taken solely and exclusirely by that establishment for the manufacture of pencils.

The tirm on the other hand, having thoronghly convineed themselves that the newly discovered blacklead was quite equal to the genume and best Cumberland blacklead in equality, willingly entertained this proposition of Alibert's, so that in the year 1856 a contract was entered into between the manufactory and Alibert and sanctioned hy the Russian fovernment, according to which all the blacklead, which comes from the Siberian mines is to be delivered to $\mathrm{A}$. W. Faber's manufactory, and to no other estallishment for the purposes of pencil manufacture, now and for all time.

It was a mighty work which the restless energy of Alibert had brought into execution in a land so difficult of aceess. On the summit of the momtain of Jatongol, which now in the linssian majs of the comntry is designated by the name of "Alibertsherg“ in honorable remembrance of the discoverer of the blacklead mine, Alibert assembled all his working force and a little colony soon sprung up, which addressed itself zealously to the new mining operations.

The miners brought the blacklead to the surtace in large hlocks and the material thus obtained proclaimed at once, by its external purity and a beautiful silvery lustre, its excellent value and composition. The transport was attended with immense lifficulties. The blocks of hlacklead, carefully packed in wooden eases, had to traverse enormous tracts of country, across which not the least vestige of a road is to be found, upon the backs of reindeer to reach the nearest seaport, whenee they were shipped to Europe, while other consiguments of the blacklead were forwarded to the mannfactory exclusively by land.

It may be conceived that Alibert by this discovery drew even the 
attention of the Russian Govermment npon himself and was gratified by the kindest encouragenent both on part of the Czar and the Governor of the provinee of Irkutsk, Count Murawiew Amursky. In the report concerning explorations in Siberia issued by the imperial Academy of Sciences the discoverer is mentioned particularly (page 33) and at the same time Faber's manufactory, the capital of which has facilitated and advanced this enterprise, is honorably spoken of.

The manufactory, thus in possession of so extensive a store of blacklead, the excellence of which both theory and practice place on a level with the Borrowdale lear, has produced peneils made with the Siberian Jead ever since the year 1856. It was now no longer a question of attaining to the standard of the Cumberland pencils but rather of surpassing it.

The new material was worked partly in a natural state so as to enable connoisscurs to convince themselves of its excellent quality and partly artificially manufactured, which yielded as a result such a degree of evenness, purity and unchanging hardness as had never before been obtained, not even in the best Cumberland pencils. After the exertions of six years the manufactory is just now intending to enter the World's market with its new productions.

Before we conclude our sketch we must stop to contemplate a bright spot in the internal history of the factory and remember the day on which it celebrated the completion of the lundrelth year of its existence witlı a festival, to which the joyful feelings of a haply and contented population and the not less hearty than general participation therein from far and near, leut a peculiar solemnity.

The festival was celebrated by the proprictor of the manufactory Johanu Lothal Falser and his brother Johaun Fabey together with their families and in the midst of the assembled factory hamb male and femalc, als also of all masterworkmen employed for the manufactory and a large mumber of invited guests.

The $16^{\text {th }}$ September 1861 was the day fixed for the oceasion, dhiefly' 
with the view of rendering the festival all the more impressive ly a special celebrntion of divine service in the new church of the village, which had onls been consecrated a fortnight before. Preparations of the mont varied character ocempied both the masters of the factory and their families for some time previously: in order to rembler this anspicions and happy esent a thoronghly joynus festisal for their worlipeople and all that participated therein, and the remembrance of it un less pleasing than indelible.

similar feelings however also actuated the workpeople, who exerted themselves with all their power to adil to the splendor of the festival, and manifest their good feelings and gratitude in a tonching and mexpectmal manner,

On the err of the fentive day the workmen in a borly bronght their master a torehlight procession, which. after passing thromgh the whole of the gaily decorated premises, came to halt in the conrtyard of Mr. Faber's houre, whereupon the workmen's singing club performed three partsongs composed expressly for the occision.

A deputation of workmen consisting of men who had been longest in the factory then hamled the master, together with an appropriate anlliens matle. by their senior member, il handsome and tasteful allum as a festive present from them, and a parchment roll on which were printed it dedication composed in verse, then the speech which a workman madr in the most spirited mamor previous to the presentation of the album, further the songs performed and a list of the names of all the workmen and women. This was certainly une of the most affecting moments and even those men, who had hecome grey in the service of the factory were unable to restrain their tears of emotion and gratitude.

Lothar Faber in his reply dwelt particularly upon how he ralued the proofs of love, attachment, gratitnde and faithfulness shown to him as heing not merely intended for himself alone but likewise for his whole house and more especially for his two brothers standing so faithfully by his side, and how he wished that these sentiments of the workpeople might ever spread among them and be manifested to him and his family for all time. 
On the morning of the sixteenth of September all the workmen and women assembled at the house of $\mathrm{L}$. $\mathrm{F}$ aber in order to receive the festive present appointed for eacl person as also a commemoration medial coined expressly for this festival, having on the one side the arms of the fanily with the legend: „Founder: Kaspar Faber † 1784; Successors: A. W. Faber $†$ 1819; G. L. Faber $† 1839$; J. L. Faber; and upon the Obverse the legend: "In remembrance of the Century Jubilee of the Leadpencil Manufactory of A. W. Faber at Stein near Nürnberg.“

The festive clang of bells now summoned all present to the special divine service, which was destined to form a worthy commencement to the festival and all the factory hands arranged themselves in a stately procession, which, headed by the members of the Faber family, moved towards the church in order there to give vent to the feeplings of gratitude in a pious and christian manner. A sermon was preached, the text being taken from the $90^{\text {ta }}$ Psalm, rerses 16.17 and at the conclusion of the service all the worlipeople male and female assembled at eleven o'clock at the workmen's dwellinghouses in the village of Stein built by L. Faber, from whence they started in a procession, headed by the band of the fourteenth regiment of infuntry stationed at Nirnberg, for the park of L. Faber, one portion of which nearest the dwellinghouse had been specially arranged for the festival partly for the entertainment of the numerons guests and partly for various amusements of play and dance, and which, by its elegant decorations and appropriate mottoes, bearing upon the past and present of the Factory, made the most agrceable impression upon every one. Arrived upon the festive grounds the entire body of workpeople about four hundred in number partook of the dimner provided for them, the regimental band performing agreeable music the while. The repast concluded, L. F aber momted a tribune especially erected for this occasion and ormamented with lifesize busts of the departed ancestors, and in a short speech set before them the chief features of the history of the manufactory, impressing mpon them, on the com- 
mencement of the second century of its existence, the value of that order and carefulness which are so indispensaluy necessary for the prosperous career of a large establishment in the reunirements of our age, and concluding with a cheer for the existence and welfare of the Factory in which all joined rociferonsly.

The two youngest boys of the family, Wilhelm the son of L. Faber ten years and Erust the son of his brother Johann, seven years of age hereupou ascended the steps and while the former greeted his father with a poem in the name of the four surviving brothers and sisters of $L$. F aber, the latter presented him with a silver goblet also in their name as a sourenir of the festival.

By three v'elock the number of the guests had increased to nearly six hundred. They amnsed themselves with all sorts of ganes, to which the drawing of prizes lent an especial charm, and with dancing round the loftly maypole erected on the grass plot, or with wandering through the frark, which was entirely thrown open, while the band charmed the ear with its performances. In the midst of this lively scene of rejoicing, which partook of the appearance of a national gathering, the Master of the Factory L. Faber, together with all others present were surprised in the most agreeable manner by the arrival of a gracious autographic missive from His Majesty the King, which read as follows:

nOn the $16^{\text {th }}$ inst. you celebrate, as $I$ am given to understand the completion of the first Century of the existence of the inanufactory founded by your ancestors and whose well earnt fame both at honic and abroad relounds to the honor of Bavarian industry. It has likewise given me special pleasure to observe the eare, with which you watch over the moral and temporal affairs of your workpeople. The festival which you are about to keep, affords me an opportunity of offering my best congratulations to you and the establishment conducterl by you with so much 


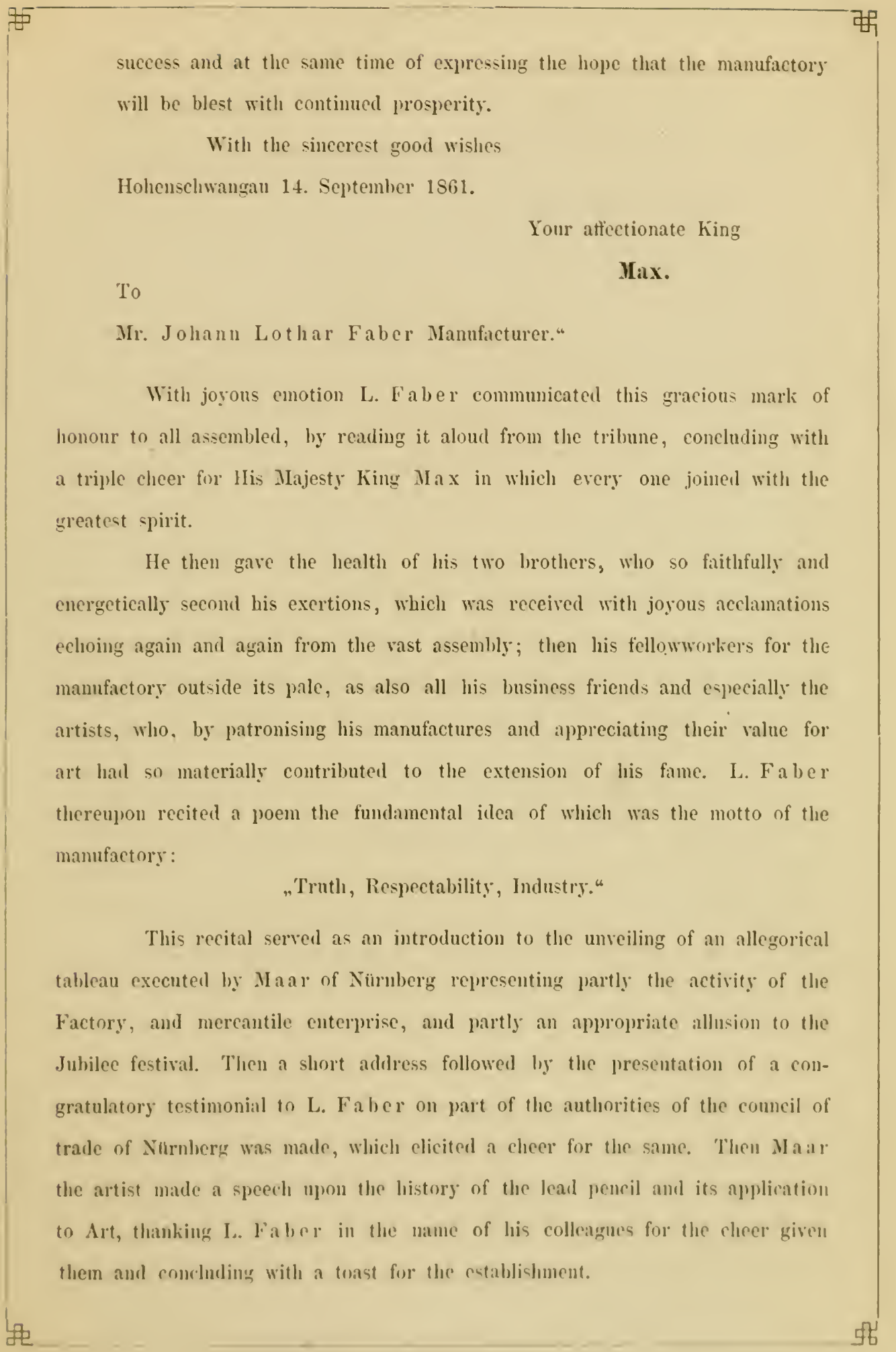


A small brochure setting forth the contents of the Festival Album before mentioned and containing a capital piece of poetry composed by a relation of the Faber fanily was then distributed among the guests.

A number of speeches and toasts were now made and given by the workmen themselves, who were fairly carried away by excitement, which one and all breathed a spirit of attachment and gratitude, and of which not a few, spite of their simple character, caused feelings of emotion. Performances of their singing clubs alteruated with those of the band until as darkness drew near the illumination of the festive grounds and an extensive portion of the park presented a fresh tableau. Bengal lights illunined several of the more lovely points and a pyrotechnic display brought the festival to a conclusion at nine o'clock, when all the participators departed in the gayest spirits and with hearty wishes for the continued prosperity of the Manufactory.

The foregoing description of the Jubilee festival of A. W. Faber's Pencil maunfactory may be appropriately closed with the mention of a transaction which was no less a gratification than an honor to the proprictor of the same:

On the morning of the eighth of October a deputation of the magistracy and representatives of the Commune of Nurnberg, consisting of the two Burgomasters, von Wächter and Seiler and the President of the College of the Conmune, Dr. Lindner, procecled to Stein in order to present Johann Lothar Fabel with the diploma of honorary citizenship of the City of Nurnberg, which reads as follows:

"The Magistrate and representatives of the Commune of the Royal Bavarian city of Nürnberg have conferred upon Mr. Johann Lothar Faber, proprietor of the Pencil manufactory at Stein in the Royal Jurisdiction of Xiurnbers, in appreciation of the many and important services, which he has rendered to industry in general and the trale of Yibrnbers in particular, by an unanimous resolution the honorary citizenship of the 
city of Nürnberg, and, after obtaining the most gracious consent of His Majesty the King, caused this deed to be drawn up for him. Given under the great seal of the city and the signatures of the two Burgomasters as also that of the President of the College of the Commune.

Nürnberg the $16^{\text {th }}$ September 1861.

$$
\text { von Wächter, I. Burgomaster. }
$$

Seiler, II. Burgomaster.

Linduer, President of the Presentatives of the Commune." afforded the proprietor of the same a welcome opportunity of dedicating this memoir to all his honoured business friends and patrons as a token of his gratitude and esteem and at the same time of giving them a pretty perfect slietch of his Factory and a riew of its internal arrangement. With this latter object he had the nine views, attached to the end hereof, taken, which represent a faithful sketch of the chief points of the establishment and by means of which it is possible to form a tolerably accurate idea of the Lead pencil Manufacture.

The first plate represents the sluicing process. On the left hand side of the picture the blacklead is seen in its original casks, on the right land side the clay. These two raw materials are here washed and then passed on in pans to be dried.

The second plate shows the grinding which goes on day and night, the composition of blackleal, clay Se. being ground fine while in a wet state, and then dried in ovens especially adapted for that purpose.

The third plate depicts the preparation of the lead. The workmen to the left in the background are forming a plastic mass of the composition by 
wetting it with water, which while still wet is passed into the eylinder of the press where it in forced throngh a copper plate, at the hottom of the cylinder, in the centre of which there is an opening of a peculiar shape. $A \mathrm{~s}$ is sern in the representation the lead thus pressed through the eylinder assumes the shape of a ring and is then earried hy the workmen on the right ujon boards and lying in a straight position, to a moderately warm place to dry. IBefore howerer the lad is completely dry, it is cut into sticks of the proper length for tilling the pencils. After the drying comes the anmealing in prenliarly construeted orens. This process takes place in hermetically closed ressel of elay or irun in which the sticks of lead are placed in a horizontal position.

In the fouth plate the method of eutting, sawing and planing the wood is seen. In the foreground to the right lies a balli of Florida Cedar wool. These balks are from 10 to 15 feet in length and 8 to 21 inches in thicliness. They are first ent across with an upright saw in picees of the length of a pencil, which pieces are then ent into sticks ly small circular saws as shown on the right hand sile of the view, the sticlis being thereupon planed smooth by the machine in front. Behind the planing machine the grooving machines are situated by 'means of which the smoothly planed sticks are cut with fine circular saws into toly and bottom pieces, the latter of which are furnished with grooves.

The fifth plate represents the process of glneing the sticks of lead into the wood. At each glueing table there are three workmen, one of whom smears the two pieces of wood with glue, while the second places the lead in the groove and the third, after the two pieces are fixed together, trims the peneils, which are then placed in a press and firmly pressed together ly means of serews. The round bundles seen in this riew are partly finished pencils and partly tops and bottoms.

At this stage of the manufacture the pencils are all synare and are now passed on to the planing shop represented in the sixth plate. There the! are ent to the exact length hy means of fine circular saws and then planed round 
or square, oval or even hexagonal or trigonal by the planing machines, which they reach in a square form.

The seventh and eighth plates show those operations which are carried on by females.

In the seventh platc to the right the worliwomen are seen engaged in polishing the pencils with colours, and to the left those who by means of a lever press stamp the name of the firm upon them.

At last the polished and stamped pencils arrive at the room, where they are made up into packets as represented in the eighth plate. Here they are fastened up in dozens, covered with tickets and packed either by the dozen or the gross.

The ninth plate represents the dwelling houses and manufacturing Premises. The residence on an elevation to the left is that of the proprictor of the Manufactory, below which is seen that of his brother. The two houses in the middle were dwellinghouses in former times and have been used for years as Countinghouse, Warehouse and Sample-show-room. The workshops lower down on the right stand close to the rirer Rednitz and the machinery therein is set in motion by watcrpower, whereas in the other premises higher up steam is the agent employed. 



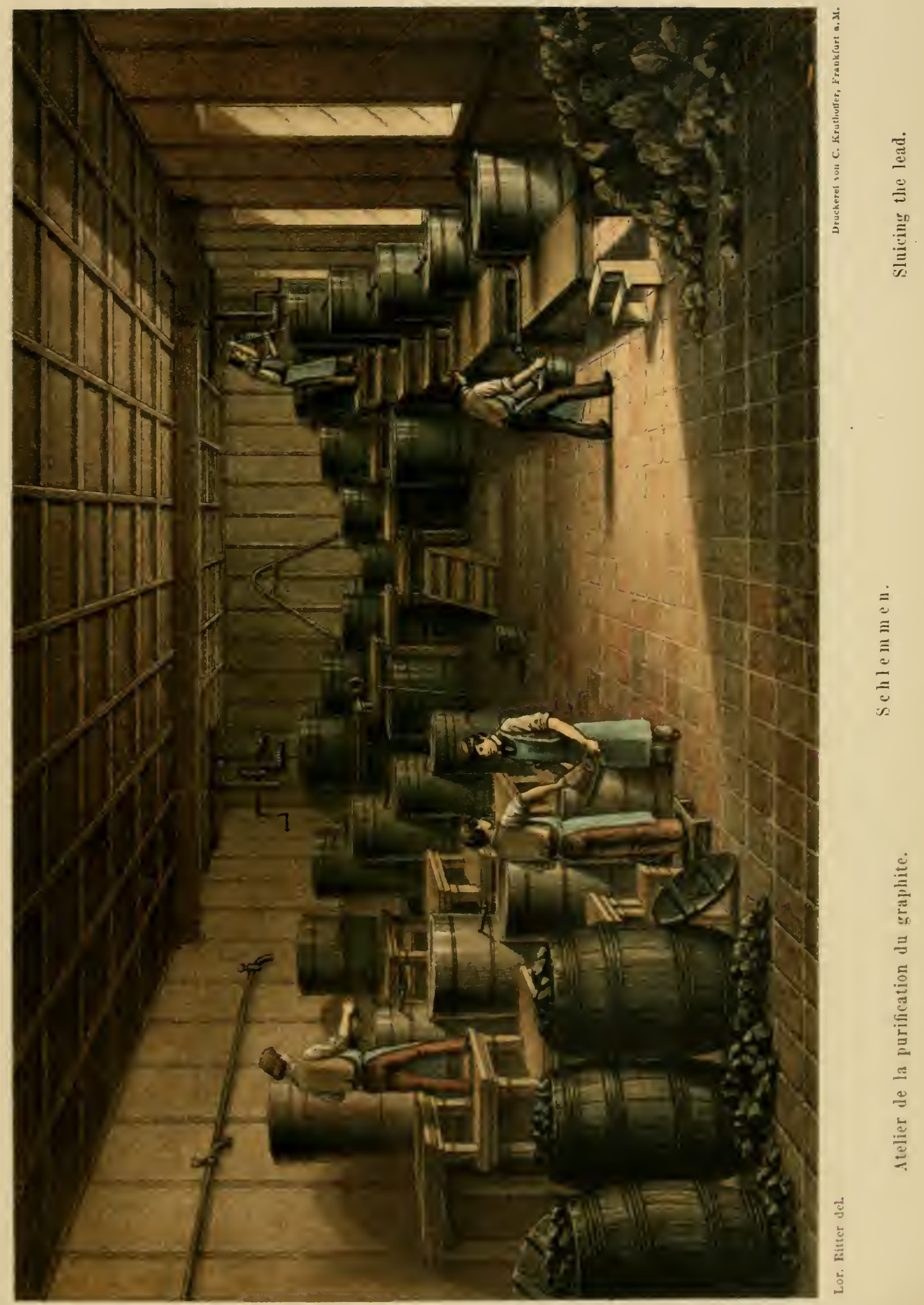





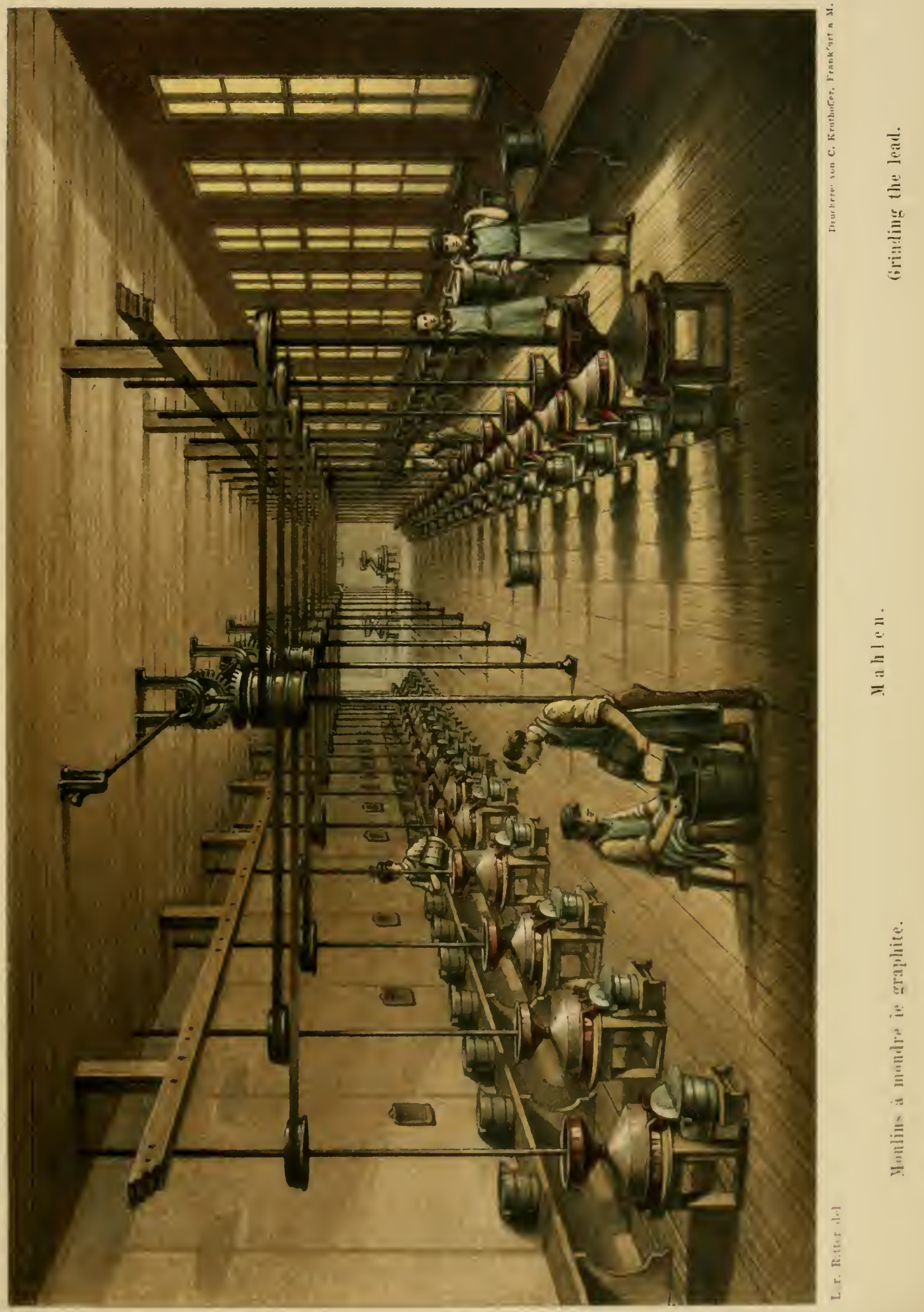





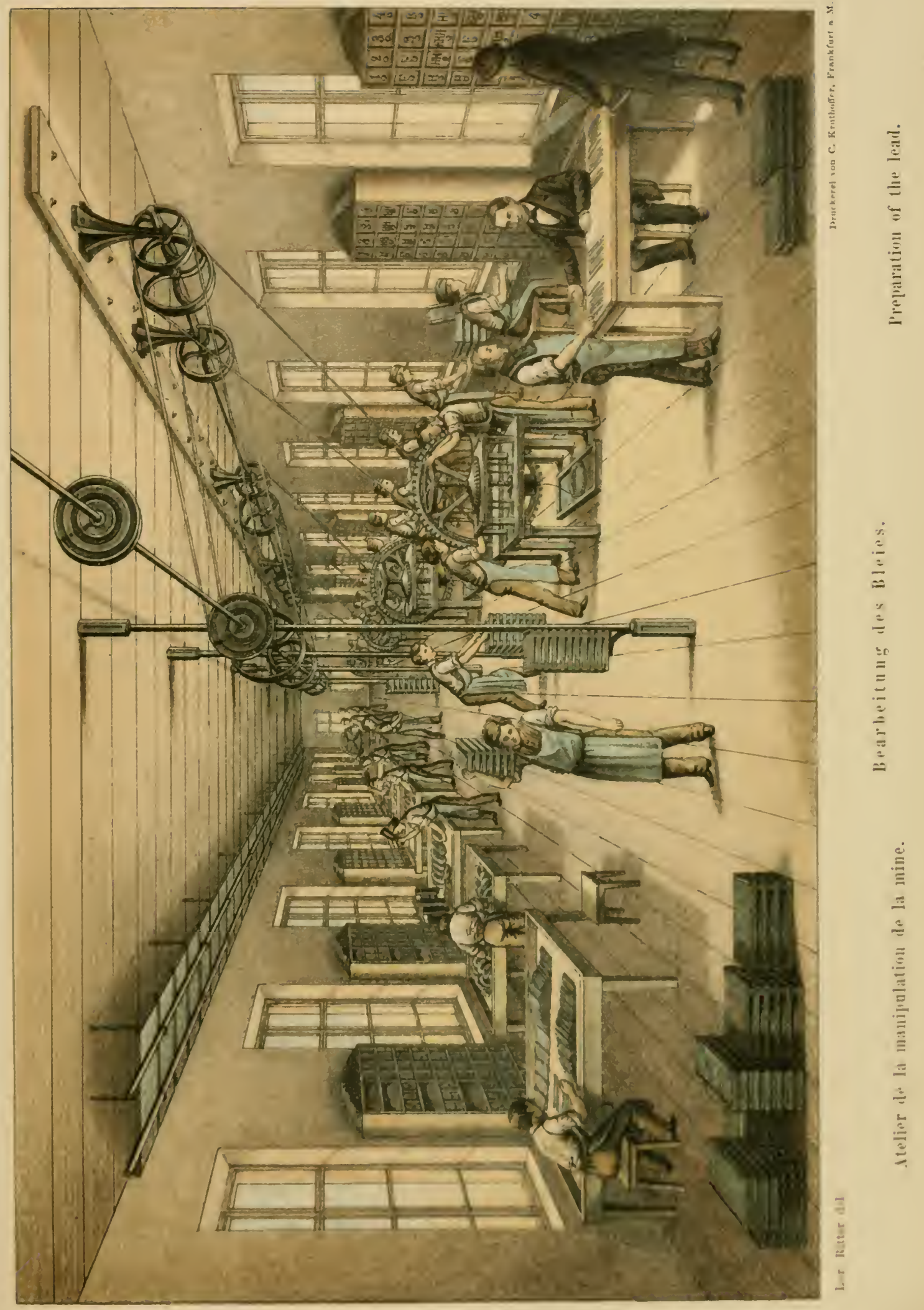





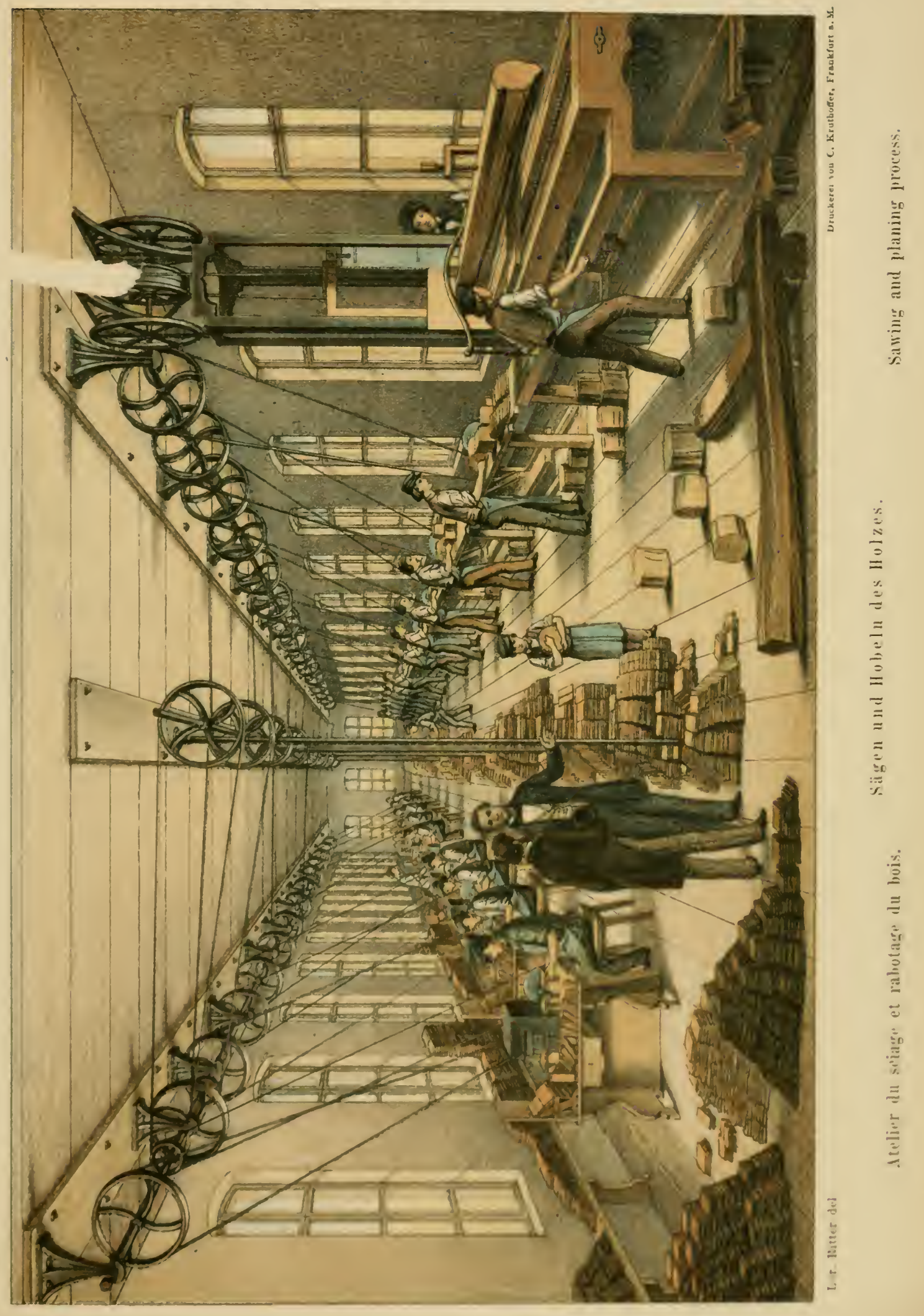





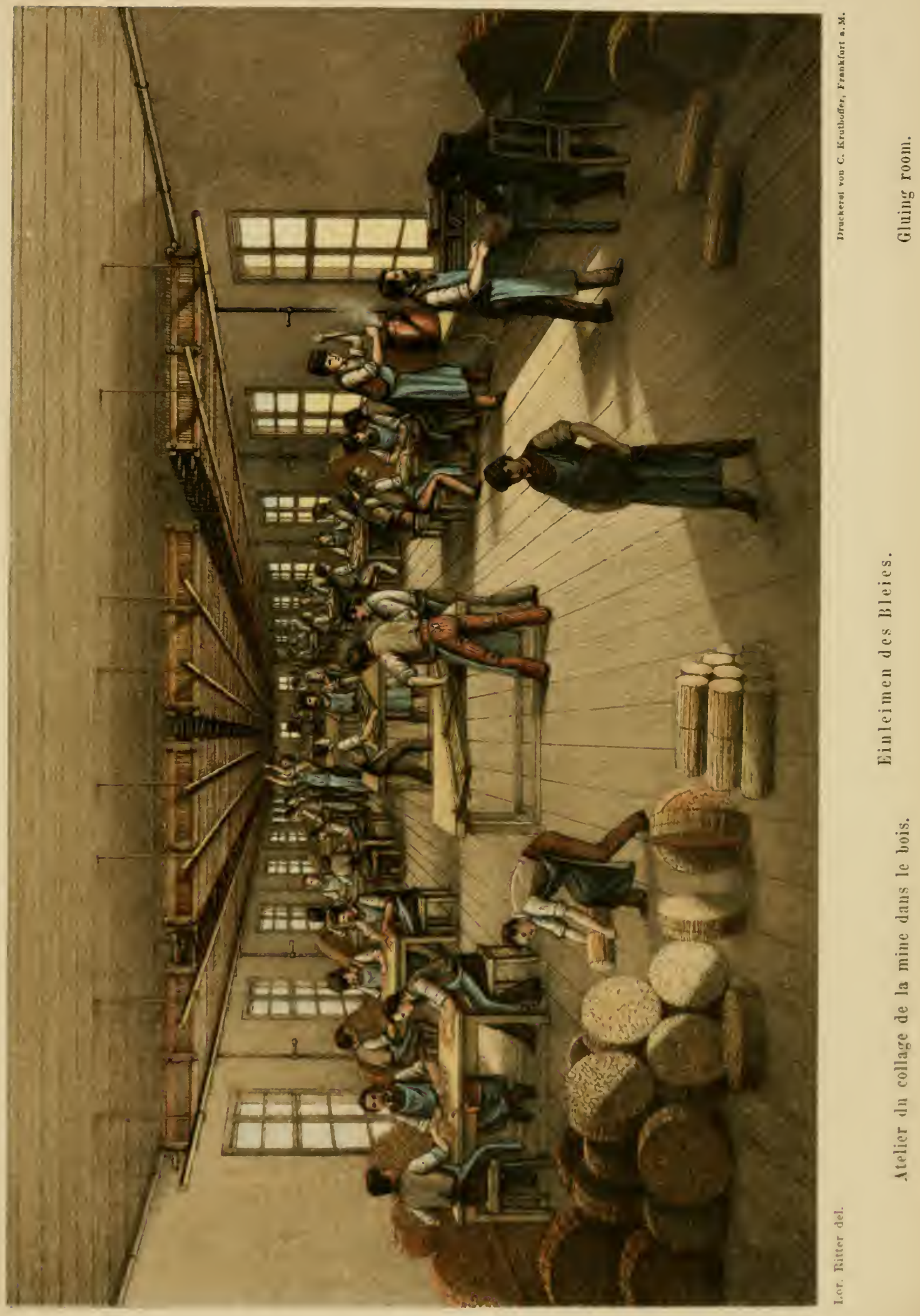





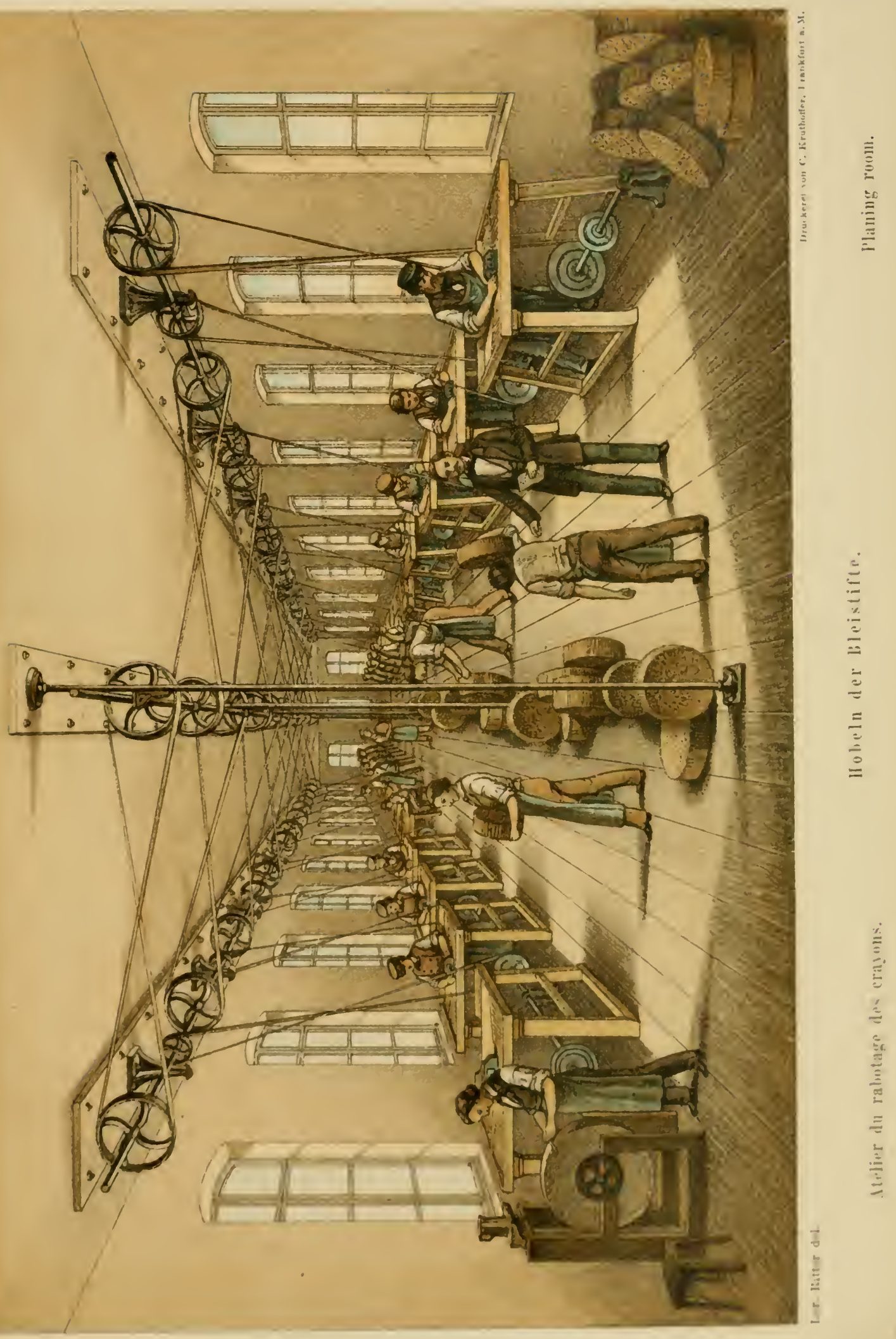





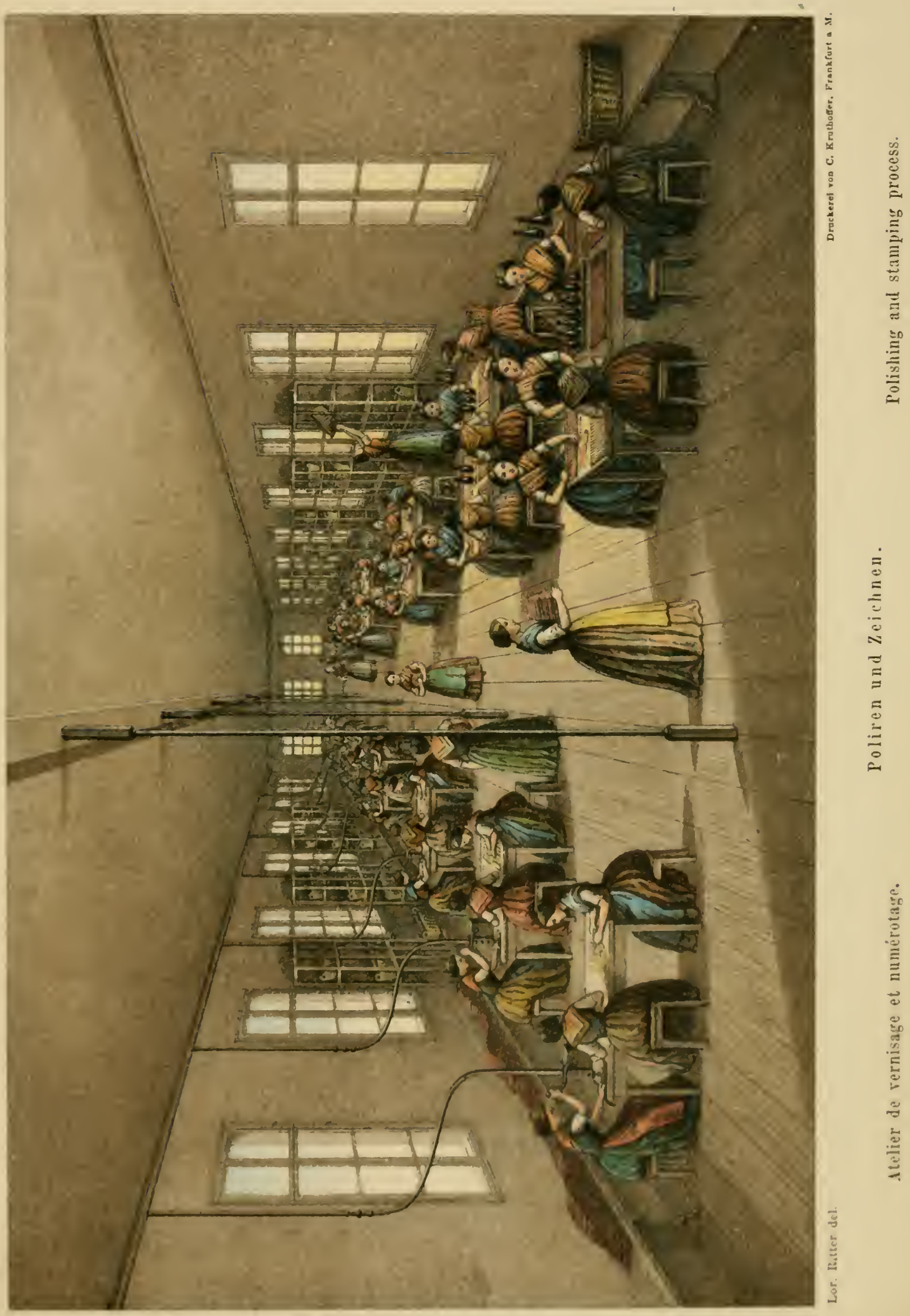





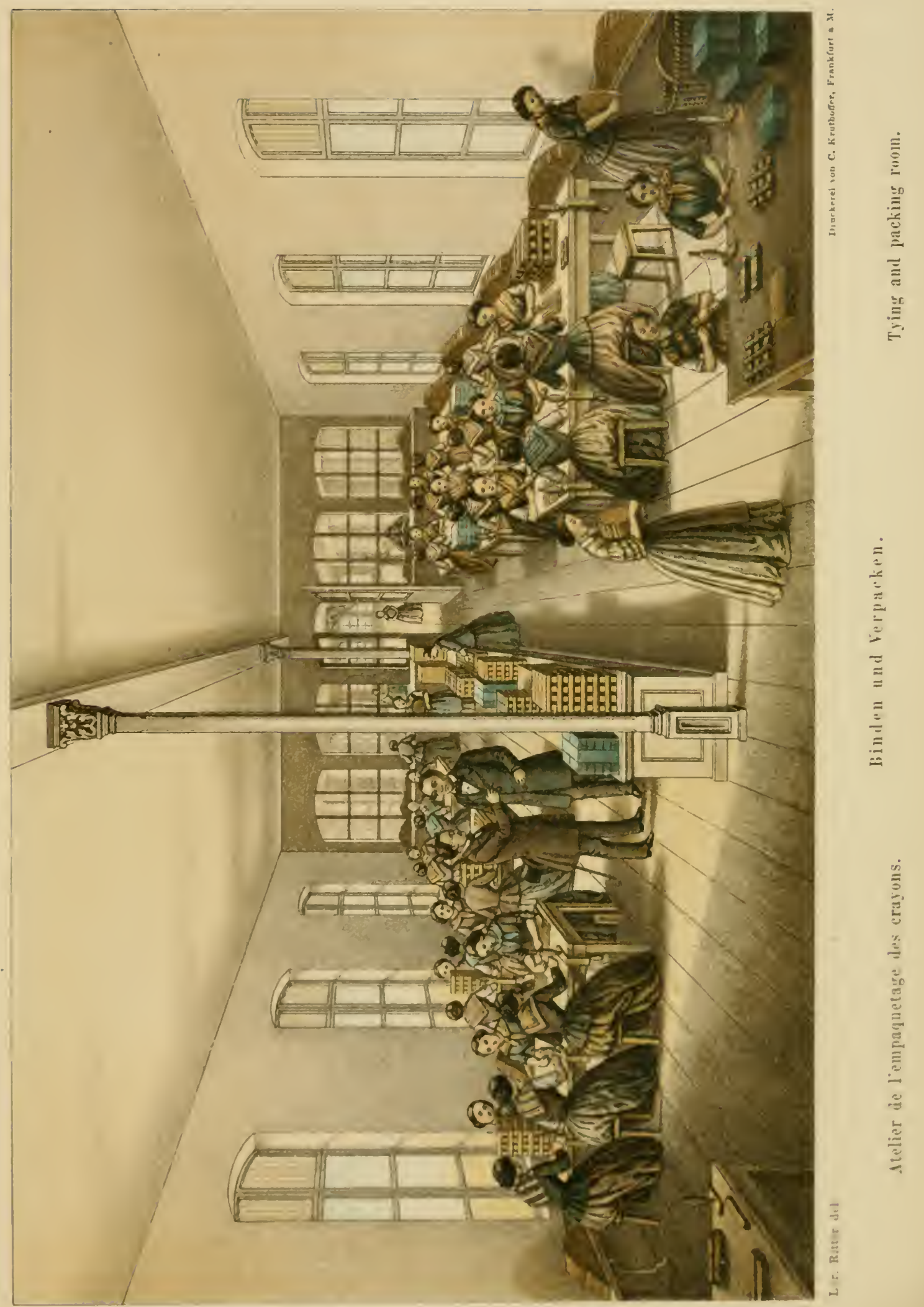





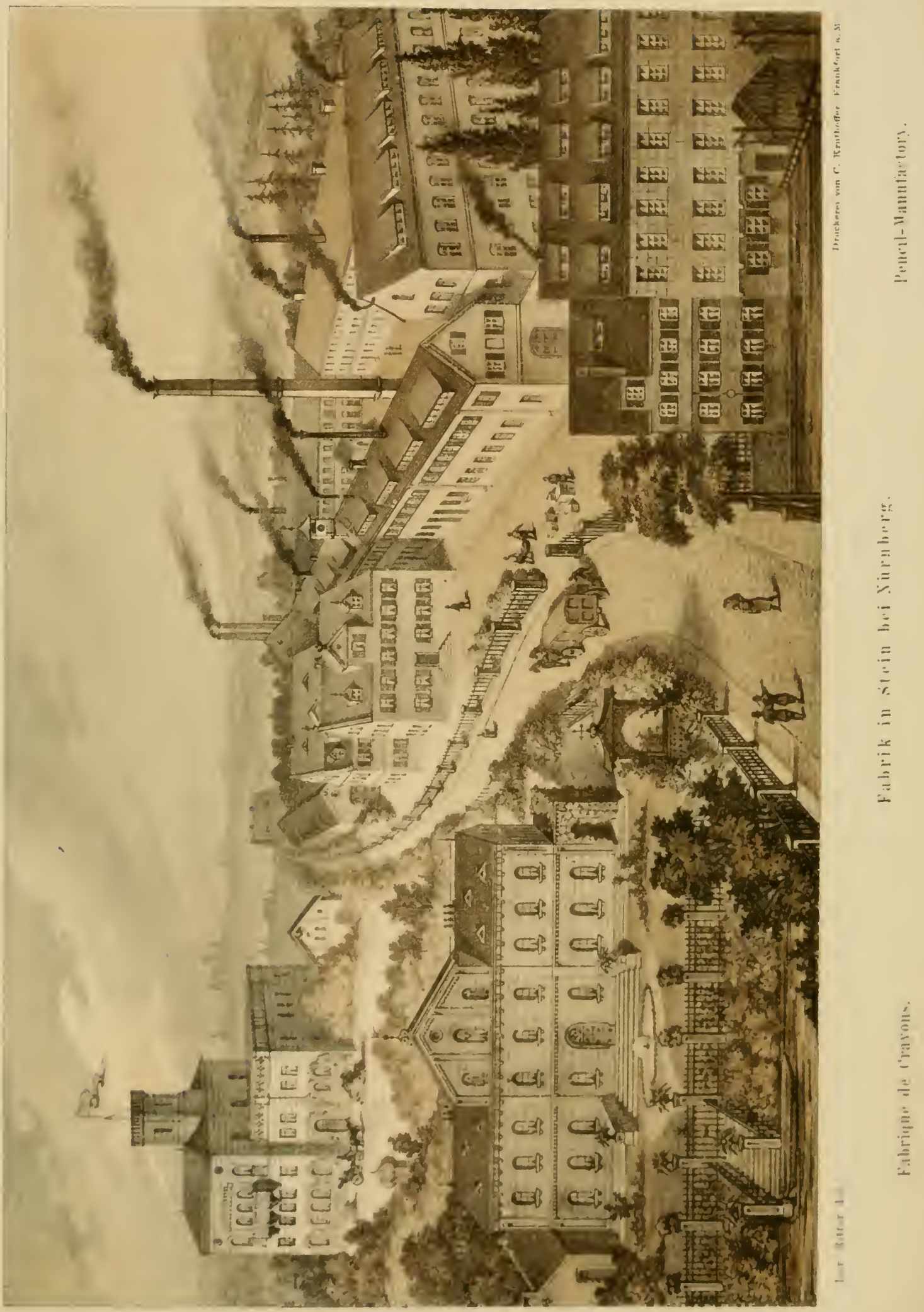



